John Chr. Jørgensen

\title{
Lille håndbog i nudansk anmelderi
}

Til Håndbog i Nudansk (1988) har Henrik Galberg Jacobsen og Peter Stray Jørgensen forfattet et opslag om “Anmeldelser” (s.32-33). De definerer anmeldelsen som "en karakteristik og vurdering af en bog, en film, en udstilling, en plade, et bygningsværk m.m.”.

Definitionen mangler ordet "ny". En anmeldelse er en karakteristik og vurdering af en $n y$ bog, film m.m. Det, der konstituerer en anmeldelse, er nyhedsmeddelelsen og vurderingen.

Hvis en skribent $\mathrm{i}$ dag publicerer en karakteristik og vurdering af Diderichsens Elementar Dansk Grammatik, vil Galberg Jacobsen og Stray Jørgensen næppe finde på at klassificere teksten som en "anmeldelse". Det skulle da være en stærkt forsinket tidsskriftsanmeldelse.

Tilsvarende kan man ikke kalde Kirstens Rasks omtale af Pia Jarvads Nye ord - hvorfor og hvordan? (i Weekendavisens B $\phi$ ger 28.7.1995) for en anmeldelse. Det er en krydsning mellem en featureartikel og en debatartikel skrevet på grundlag af nogle nyudgivne bøger, som den ikke forholder sig vurderende til.

For at vende tilbage til Galberg Jacobsen og Stray Jørgensens definition af en anmeldelse, så er deres "m.m." efter "en plade, et bygningsværk" en fornuftig helgardering. Stadig flere fænomener gøres til genstand for anmeldelse, og det er ganske vanskeligt at finde det overbegreb, som dækker alle anmeldelsesmulige genstande og foreteelser.

I 1990 rasede en række fynske præster over, at Fyns Amts Avis havde tilladt sig at anmelde de lokale gudstjenester og uddele op til fire "salmebøger" alt efter, hvor godt anmelderen havde følt sig betjent, guds-betjent?

$\mathrm{Nu}$, hvor vi taler om de højeste ting, så inddrog New York Times i december 1990 selveste Julemanden under anmelderiets domæne. Avisen uddelte "sukkerstænger" til stormagasinernes Santa Claus'er. De blev bedømt på deres udseende, troværdighed og livsfilosofi.

Anmelderiet har ekspanderet horisontalt i et sådan omfang, at det også registreres i en bog, der handler om nye ord. Pia Jarvad registrerer 
"Bogarthatte" for film, "fodboldstøvler" for landskampe, "murskeer" for boligbyggerier, "indkøbsvogne" for supermarkeder, "nissehuer" for julebryg, "toiletruller" for offentlige toiletter - og "præstekraver" for gudstjenester, da Weekendavisen i 1993 kopierede ideen fra Fyns Amts Avis (Nye ord s.266).

Hvad angår den brugsgenstand, der hedder ordbøger, så har vi i Danmark haft en tilvænningsperiode på mere end 250 år.

Det var en ordbogsanmeldelse - karakteristisk nok en retskrivningsordbogsanmeldelse - der fremprovokerede det første program for et kritisk anmelderi i Danmark.

Juristen, sproglæreren, digteren og journalisten Thomas Christensen Clitau anmeldte i 1741 Et lidet Orthografisk Lexikon af Niels von Haven - et værk, der ifølge undertitlen skulle være skrevet "Alle Elskere af det Danske Sprog til Fornøyelse, og den studerende Ungdom til Nytte"; og det var just forfatterens selvgratulerende adressering, der bragte anmelderen i den grad i harnisk, at han skrev en kritik med konklusionen: "Jeg vil alleneste raade den studerende Ungdom, at den lader denne Bogs Ret-Skrivelse fare".

Anmeldelsen gav anledning til modkritik, og Christensen Clitau hævdede sin ret til i lighed med journalister i alle andre lande i Europa at "kalde hvidt hvad der er hvidt, og sort hvad der er sort" (se videre $\mathrm{i}$ min bog om Det danske anmelderis historie, 1994 s.23ff).

Thomas Christensen Clitau dømte von Havens ortografiske leksikon intentionalt - dvs. på forfatterens fremlagte hensigter, i dette tilfælde ambitionen om at gøre sig nyttig for bestemte brugergrupper.

Dét skulle vise sig at være en særdeles slidstærk kritisk metode.

Man ser den f.eks. anvendt 250 år efter i tidsskriftet Hermes 7/91, hvor Grete Duvå afslutter sin anmeldelse af en dansk-fransk erhvervsog økonomiordbog sætningen: "Jeg kan derfor ikke anbefale hverken "studerende, forretningsfolk eller sproginteresserede i almindelighed" af anskaffe denne bog." Ligesom Christensen Clitau bruger Duvå ordsbogsforfatterens ord mod ham selv - steger ham i hans eget fedt.

Det er præcis denne intentionale vurderingsmetode, Galberg Jacobsen og Stray Jørgensen anbefaler i Håndbog i Nudansk. De udtrykker sig ganske vist i opbyggelige vendinger (som om de gav udtryk for deres egne hemmelige forhåbninger til en anmeldelse af Håndbog $i \mathrm{Nu}$ - 
dansk): "Fremstillingen i en anmeldelse bør normalt være loyal over for forfatterens hensigt med bogen. Det er nemt nok at kritisere ud fra krav man selv opstiller, men som det aldrig har været forfatterens mening at værket skulle opfylde.[...] Vurderingen (ros og kritik) bør ske ud fra bogens egne krav og dens eget sigte (som man evt. må fortolke sig frem til)".

Den intentionale kritik vil altid står stærkt. Under devisen "Du skal holde dit ord" legitimerer den så at sige sagkritikken moralsk.

Men i Galberg Jacobsen og Stray Jørgensens serviceorienterede sprogbrug underbetones metodens kritiske potens, og hvad værre er: De to forfattere er nær ved at gøre den intentionale metode til den eneste gangbare.

Deres grundopfattelse af anmeldelsen er, at den skal orientere om udgivelsen af en ny bog - de befinder sig stort set dér, hvor Holberg befandt sig, da han midt i 1700-tallet kritiserede det frembrydende anmelderi (Det danske anmelderis historie s.22f). Efter at have opremset de hovedpunkter, en anmeldelse efter deres mening bør indeholde - "Indholdsreferat", "Hensigten med bogen", "Vurdering" og "Standardoplysninger" - tilføjer Galberg Jacobsen og Stray Jørgensen under den sigende overskrift "Ekstra service", at en anmeldelse også kan indeholde oplysninger om bogens baggrund (historisk, samfundsmæssigt, videnskabeligt, teoretisk, aktuelt), dens placering i forfatterskabet, dens særlige problemstillinger og dens forhold til andre værker med samme emne.

I anmeldelser af ordbøger forekommer det sidste moment - en ny ordbogs forhold til andre beslægtede ordbøger på markedet - uomgængeligt.

Når Ole Lauridsen i Hermes 13/94 anmelder Gads Tysk Large (hvilket absurd navn forresten) af Carsten Hansen (til gengæld et udmærket navn), så ligger der som implicit krav, at anmelderen forsøger at forklare læseren, hvad man her får for pengene i sammenligning med, hvad man får, hvis man køber markedets standardværk fra Gyldendal.

På denne måde forekommer det også naturligt, at Orla Vigsø i Hermes 16/96 fremlægger en sammenlignende anmeldelse af Pia Jarvads Nye ord - hvorfor og hvordan? og den ligeledes i 1995 udkomne artsbeslægtede Engelsk $i$ dansk. Er det et must? af Knud Sørensen; her er pointen at sætte den ene bogs holdning til engelskpåvirkningen af det 
danske sprog i relief ved sammenligning med det andet værk, således at man som læser ved, hvad man går ind til rent sprogpolitisk. Vi læser jo også for at få bekræftet (sjældent desværre afkræftet) vore egne meninger.

Anmelderiets historisk-samfundsmæssige begrundelse ligger i fremvæksten af et marked, hvor forbrugeren har behov for orientering. Jo mere direkte brugsrettet en ny vare er, des større er behovet for en sammenligning med de varer, der tidligere har opfyldt samme behov.

Som en Anders Bodelsen i sine motorcykelanmeldelser sammenligner den ny Honda-model med den gamle, således sammenligner Karen M. Lauridsen i Hermes 7/91 den ny udgave af Vinterberg og Bodelsen med den gamle. Ja, ligesom Anders Bodelsen prøvekфrer hun også modellen. Én ting er jo, hvordan den klarer sig på lige vej i stille vejr, noget andet er, hvordan stabiliteten er, når der køres op ad bakke $\mathrm{i}$ stærk sidevind. Karen M. Lauridsen tager en dagfrisk avisartikel om EU og ser, hvor mange af ordene, den person, som skal oversætte artiklen til engelsk, vil få ordentlig hjælp til i ordbogen. For få, synes det.

I ordbogsanmeldelser har vi foruden den intentionalkritiske metode således også den komparationskritiske, og hvad vi kunne kalde den testkritiske.

Noget tyder på, at de typer af bøger, vi har med at gøre, stiller særlige krav til dem, der skal anmelde dem. Det er for så vidt ikke til at undre sig over. Den vurdering, som sammen med nyhedsmeddelelsen konstituerer anmeldelsen, må nødvendigvis rette sig mod særegenhederne, herunder de særlige brugsfunktioner, i det værk, der anmeldes. Det vil på jævnt dansk sige, at forskellige slags bøger åbner sig over for forskellige former for kritik. Også i anmeldelsens deskriptive dele - nyhedsmeddelelsen og karakteristikken - stilles der selvfølgelig forskellige krav til fx en fagbogsanmeldelse og en romananmeldelse, idet den sidste jo almindeligvis indebærer en eller anden selv nok så nødtørtig form for handlingsreferat.

I Det danske anmelderis historie (s. 46) skelner jeg mellem anmeldelsens konstituenter - nyhedsmeddelelsen og vurderingen - og dens ekstenter, dvs. anmeldelsens uddybende eller "forlængende" momenter, hvortil jeg blandt andet henregner sammenligninger med andre forfatteres værker. 
Men hvis sådanne sammenligninger i bestemte typer af anmeldelser nu viser sig at være konstituerende, knager det lidt i definitionssystemet - ikke i systemets kernekonstruktion, for ordbogsanmeldelsens komparationer tjener jo et vurderingsformål - men i udenværkerne. Ekstenterne kan nemlig i så fald ikke monteres af og på efter forgodtbefindende. En ordbogsanmeldelse synes helt inde i kernen at være anderledes end den skønlitteraturanmeldelse, som - måske i højere grad, end jeg har gjort mig det klart - ligger neden under mine teoridannelser.

Galberg Jacobsen og Stray Jørgensens basis er tydeligvis fagbogsanmeldelsen.

Det afslører de ufrivilligt med en formulering i det lille afsnit, der hedder "Hensigten med bogen". Her skriver de: "Især ved skønlitteratur må man ofte lave en fortolkning for at finde frem til værkets egentlige mening". - Som om litteraturkritikkens opgave var at pakke indholdet fri af formen. Som om et litterært værks betydning alene beroede på dets budskab og ikke på den læseoplevelse, som samspillet mellem form og indhold giver.

Galberg Jacobsen og Stray Jørgensen forholder sig især til ræsonnerende sagprosa. "Er der en sammenhængende og acceptabel argumentation?" er et af de generelle (og altså ikke nødvendigvis intentionelle) vurderingsspørgsmål, man ifølge dem kan stille til en bog. Det lyder ræsonnabelt.

Men når forfatterne $\mathrm{i}$ den efterfølgende sætning forsøger at udvide kriteriets gyldighedsområde til fiktionsprosa, røber de det rationalistiske, instrumentelle grundlag for hele deres tænkning over anmeldelsen: "Er der valgt en fornuftig historie, persontegning, metode, teori". Om "fornuftige historier" kan man i skønlitteraturen højst tale, når det handler om eksplicit didaktiske bøger, fx problemopløsende tryksager for børn og unge. Ellers er der som bekendt så utrolig meget "ufornuft" og føleri i litterær kunst, at man er tilbøjelig til at betragte det som tegn på kvalitet.

At Galberg Jacobsen og Stray Jørgensen har fagbogsanmeldelsen i tankerne fremgår endelig også af deres genkommende, for ikke at sige redundante, appeller til saglighed og loyalitet: "Fremstillingen i en anmeldelse bør normalt være loyal over for forfatterens hensigt med bogen. [...] Den almindelige (og evt. uprofessionelle) anmelder står sig ved en saglig, neutral fremstilling [...] En anmeldelse bør være loyal 
over for forfatterens hensigt med bogen. Fremstillingen i en anmeldelse bør være saglig og neutral". Grunden til, at de med så stor ildhu hamrer denne pointe fast, fremgår andetsteds af deres tekst. De er bekymrede. De har et skræmmebillede, som de hurtigt stikker frem for deres læsere: "Mange professionelle anmeldere i dagblade og tidsskrifter har deres helt personlige og særprægede form som kan være mere eller mindre brugbar for den læser, der vil have saglig oplysning om en bog. Tit bliver selve anmeldelsen og anmelderens personlige meninger vigtigere end bogen, anmeldelsen bliver til underholdning." Og så følger listen over alt det, en ikke-underholdende anmeldelse ifølge Galberg Jacobsen og Stray Jørgensen skal indeholde.

Det skræmmebillede, der spøger i forfatternes fremstilling, har vi i den klassiske danske skønlitteratur en førsteklasses levendegørelse af. Det er Christian i Hans Egede Schacks Phantasterne (1857). Han drømmer på et tidspunkt om at blive en stor kritiker; og hans grundsynspunkt skal være, "at det kritiserede Værk skal tjene Kritiken." Christian har annammet den opfattelse, at "Kritiken skal være en selvstændig genial Produktion, der benytter vedkommende Værk til at skaffe sig Tilværelse, og ved hjælp deraf erholder sig forhøiet Interesse." (Hans Hertels udgave 1970 s.113). Metoden består i, at kritikeren får et "genialt eller piquant Indfald". "Derpaa tager man den Bog, som skal kritiseres, for sig og udfinder Ligheden mellem den og det, man saaledes i sine Tanker har udført." (smst). Jo flere ligheder, kritikeren finder, des mere kommer han til at anerkende forfatteren, og des mere interessant kan han gøre sin egen personlighed gældende i stilen. Et lykkeligt interessesammenfald, må man sige. Christian refererer sin mentor, redaktør von Pommeren, for det synspunkt, at kritikken ville blive lige så kedelig som værkerne selv, hvis bladenes kritikere bare optrådte som "tjenende Aander" for de kritiserede bøger. Von Pommeren, som selv indleder en anmeldelse af Sibberns Logik med sætningen "Jagten, Halloh! - Hvilket herligt Tidsfor driv for Mænd!", ville utvivlsomt tage skarpt afstand fra de kedsommelige muligheder for journalistisk udfoldelse, der ligger i Galberg Jacobsen og Stray Jørgensens recensionskogebog, som går ud på, at man starter med et referat og derefter går over til forfatterens hensigt og efter yderligere fire punkter endelig når frem til vurderingen.

Sådan ser end ikke de mest saglige fagbogsanmeldelser ud, skrevet i fagtidsskrifter for de mest motiverede fagfæller. Faktisk har vi siden 
Jacob Badens og Adresseavisens Kritiske Journal i 1768 haft mere raffinerede retoriske mønstre for recensionsvirksomhed end dem, Galberg Jacobsen og Stray Jørgensen tilbyder deres læsere i Håndbog i Nudansk i 1988.

Jeg har nogle gange prøvet at fremlægge Galberg Jacobsen og Stray Jørgensens opslag om “Anmeldelser" for dels kulturformidlingsstuderende på universitetet og dels kulturjournalister på efteruddannelse. Håndbog i Nudansk præsenterer sig jo som "en opslagsbog i praktisk sprogbrug" og den skulle - stadig ifølge forfatternes forord - kunne bruges bl.a. af "studerende og andre uddannelsess $\varnothing$ gende".

De studerende på universitetet synes umiddelbart, at artiklen giver dem en nyttig oversigt over anmeldelsens ingredienser. De professionelle journalister, som tænker i skrivning, konstaterer hurtigt, at en efterlevelse af håndbogens anvisninger vil resultere $\mathrm{i}$ tekster, der $\mathrm{i}$ hvert fald ikke kan trykkes i nogen dansk avis i dag.

Nogle af de kvikkeste studerende og næsten alle de professionelle kulturjournalister er klar med fingeren, når jeg stiller det ledende spørgsmål: "Er der træk ved det praktiske anmelderi, som I savner oplysning om i artiklen om "Anmeldelser" i Håndbog i Nudansk"?

I betragtning af, at håndbogen ikke bare er et redskab til analyse, men udtrykkeligt vil være "en hjælp til at fremstille hele tekster" ("Forord"), er det ret opsigtsvækkende, at den 1) ikke med ét ord nævner, at anmeldelser, fordi de forholder sig til nyheder, almindeligvis også skrives inden for en bestemt, ret snæver tidsfrist, og 2) at den end ikke antyder, at anmeldelser, fordi de trykkes i aviser eller tidsskrifter, almindeligvis skal holde sig inden for bestemte pladsrammer.

Det er jo ikke enhver beskåret som Søren Kierkegaard at tage en anmeldelse, der var bestemt for et fire sider stort tidsskrift - Carl Plougs Nordisk Literatur-Tidende - og løfte den ud i en selvstændig bogform, fordi den blev lidt for lang. En littercer Anmeldelse kaldte Kierkegaard sin 114 sider lange bog om Thomasine Gyllembourgs To Tidsaldre.

Da jeg skrev min disputats om Det danske anmelderis historie, troede jeg, at Kierkegaards anmeldelse satte længderekord for boganmeldelsen i Danmark. Men det viste sig, at rekorden kun gjaldt for anmeldelser af $s k \phi n l i t t e r a t u r$.

Der findes en fagbogsanmeldelse, der er længere. Ja, faktisk er det en anmeldelse af et tidsskrift, Johan Ludvig Heibergs Perseus, som af F. C. 
Sibbern blev anmeldt i et andet tidsskrift, Maanedsskrift for Litteratur i 1838. Anmeldelsen løb over i alt 336 sider og var fordelt over 8 numre (hvorefter tidsskriftet gik ind). Sibbern tog så grundigt fat på det, der i Håndbog $i$ Nudansk kaldes baggrunden for bogens indhold, at anmeldelsen samme år kunne publiceres i bogform under titlen Bemarkninger og Unders $\phi$ gelser, fornemmelig betreffende Hegels Philosophie, betragtet $i$ Forhold til vor Tid.

Eksistensen af Sibberns anmeldelse blev jeg gjort opmærksom på af en kollega i Odense, Knud Bjarne Gjesing. Det skete såmænd i en anmeldelse, tilmed i en avis, Århus Stiftstidende (30.12.94). Hvilket viser, at en fagbogsanmeldelse kan fungere som mere og andet end en anbefaling eller en advarsel. Dér, hvor den fx korrigerer konkret ved at fremlægge overset empirisk materiale, kommer den til at virke den som en integreret del af en fælles fortløbende udforskningsproces.

I forbindelse med modtagelsen af ordbøger, leksika og værker som Pia Jarvads Nye ord - hvorfor og hvordan kan man sige, at anmelderne fungerer som "meddelere". De hjælper med at samle materiale sammen.

Således har Ole Lauridsen i sin anmeldelse af Gads Tysk Large (Hermes 13/94) gjort Carsten Hansen opmærksom på, at verbet "forstå" bør optages i en eventuel ny udgave af ordbogen. Anmelderen siger stilfærdigt, at det nok er en lapsus, at ordet ikke er med. Han synes ligesom Paul Lindegård Hjorth $\mathrm{i}$ den kløgtige artikel om ordbogsanmelderi $\mathrm{i}$ Leda ( Nyhedsbrev nr.14, februar 1994) at være tilhænger af princippet Fortiter in re, suaviter in modo, - stærk i sagen, mild i måden.

Anderledes sagt: Jo stærkere man står rent sagligt, des mere afdæmpet kan man føre sin kritik frem.

Når Anna-Lise Laursen og Sven Tarp skriver om Orlando Galindos dansk-spanske fagordbøger (i Hermes 7/91), at man godt kan bruge ordbøgerne, hvis man efterkontrollerer alle oplysningerne i andre opslagsværker, så har de vist udtrykt sig tilstrækkeligt tydeligt.

Det fører mig over til arbejdet med anmeldelsens stil og form. Her er der forbavsende nok heller ikke megen hjælp at hente hos Galberg Jacobsen og Stray Jørgensen, skønt de som sagt vil lære læserne at skrive hele tekster. Hvordan gør man det uden at have redskaber til sammenbinding? 
De to håndbogsforfattere forbigår de skriveproblemer, det giver at skulle konsumere et stort stof på kort tid og derefter komprimere det læseligt inden for beskedne pladsrammer.

De overser også, at anmeldelsen, hvad enten den står i en avis eller et fagtidsskrift, og hvad enten den forholder sig til en populær roman eller et vanskeligt tilgængeligt videnskabeligt værk, skal kunne fange læserens opmærksomhed og holde den fast. Til enhver boganmeldelse findes der rigtignok enkelte pligtlæsere - forlagsredaktøren læser fx anmeldelser af de bøger, han eller hun har ansvaret for, ligesom redaktøren af en dansk-tysk/tysk-dansk-ordbog formentlig ikke under nogen omstændigheder vil springe over en anmeldelse af en kollegas dansk-tysk/tysk-dansk-ordbog - men pligtlæserne er i alle tilfælde få. Leksikografer skriver ikke kun for leksikografer, men også - og især for brugere af ordbøger og opslagsværker, fx undervisere og oversættere.

Selv blandt læserne af et lingvistisk tidsskrift som Hermes, vil der formentlig være en del, der kan finde på at springe over en anmeldelse, fordi den ikke umiddelbart ser interessant ud. Formularagtige indledninger som "Endelig kom den længe ventede 3. udgave af Vinterberg og Bodelsen" (7/91 s.123) og "I efteråret 1990 udkom det blandt studerende og mange oversættere imødesete opslagsværk dansk-tysk teknisk ordbog" (7/91 s.139) kunne for eksempel tænkes at virke en kende demobiliserende på læselysten. Den slags indledninger var klichéer allerede i 1700-tallet. På den anden side kan det værk, anmeldelsen handler om, i kombination med en usvigelig tiltro til anmelderens kompetence få faglæseren til at overvinde mange læseforhindringer.

I en avis ville det ikke gå an. Her må man som skribent være sig bevidst, at man konkurrerer om læsernes opmærksomhed. Her må man bruge de greb til identifikation, dramatisering og aktualisering, som f.eks. optræder i Thomas Bredsdorffs og Ivar Gjørups anmeldelser af sprogvidenskabelige værker i Politiken (hhv. Dфde metaforers klub om Lakoffs Moral Politics 6.10.96 og Ordets glaeder om Jarvards Nye ord 7.5.95). Disse avisartikler er med deres ordlege, deres anekdotiske indslag og deres direkte læserhenvendelse også skrevet med henblik på lystlæsning - kald det bare underholdning. Det er min påstand - som jeg mener de nævnte artikler underbygger - at det er muligt at skrive underholdende uden at give afkald på saglighed - som ikke er det samme som 
loyalitet og neutralitet, for nu for n'te og sidste gang at sparke til forfatterne af Håndbog i Nudansk.

De er velkomne til at kalde det en dårlig anmeldelse!

Lad mig slutte i den nyheds- og underholdningsbranche, hvor jeg som anmelder befinder mig (i øvrigt godt) i dag: på Ekstra Bladet, en avis, der hver dag skal sælges i løssalg til 160.000 købere, kun ca.10.000 abonnerer - en avis, der er kendt for at være direkte, fræk og aggressiv, og som meget gerne vil være underholdende. Avisen har et meget stort ungt publikum, en vis overvægt af mandlige læser i Københavnsområdet, men ellers repræsenterer den socialt, geografisk osv. et gennemsnit af landets befolkning. Den har også læsere til boganmeldelser. Anmeldelserne er i almindelighed kortere end dem i morgenaviserne, men de kan også fylde mere, når der er opsigtsvækkende værker på tapetet. Værker som Sabroes Sidste tog og enkeltbind af Den store Danske Encyklopadi har fået helsidesanmeldelser, det gælder også, hvad man skulle tro var mere specielle sager som Aschehougs Lasebogen og Odense Universitets Lasninger i dansk litteratur. I de sidste to tilfælde, som Hans Flemming Kragh har taget sig af, er det mindst lige så meget anmelderens skrive- og overtalelsesevne, som det er værkernes gennemslagskraft, der har skaffet rum i avisen. Af anmeldelsesmaterialet omkring Pia Jarvads bog fremgår det også, at der kan skrives udførligt og kompetent i aviser (Gjørup i Politiken 7.5.95).

Anmeldelser, også af sprogbøger, kan være som attraktivt læsestof i avisen. Det forudsætter, at det får en journalistisk vinkling, og at artiklerne er håndskrevne, som vi siger pressen. Det vil sige, at der er kælet for sproget - at anmeldelsen er komponeret.

Selv i en avis som Ekstra Bladet kan anmeldelser af bøger af lingvistisk og litteraturteoretisk art komme på tale. Jeg skrevet et par stykker af dem selv; de er ikke på ekspertplan, men på, hvad man kunne kalde professionelt brugerniveau.

Jeg slutter med tre sådanne EB-eksempler af egen avl, ikke fordi de skal betragtes som forbilledlige for anmelderi noget andet sted - jeg skriver ikke så summarisk, når jeg lejlighedsvis anmelder fx i Danske Studier - men fordi disse anmeldelser på en ekstremt tydelig måde udstiller problemerne ved at arbejde hurtigt og formulere sig kontant og "pikant" (for nu at bruge et af Schacks problematiserende ord fra Phantasterne). Man er nødt til at skære hurtigt igennem til anmeldelsens 
grundmomenter: Er der en nyhed? Er den god eller dårlig? Jeg skal medgive, at det ikke $\mathrm{i}$ alle tilfælde er muligt at leve op til det Tom Kristensen-ideal, som jeg ellers hylder - at man skal give en impression af værket, så læseren kan gribe ind mellem anmelderens særinteresser og særlige sympatier og måske finde ud af, at den og den nedrakkede eller lobhudlede bog er noget for ham (Kritiker eller Anmelder, Politiken 30.7.1940, optr. s.309ff i Tom Kristensen: Til Dags Dato, 1953).

Pudsigt nok har jeg givet alle tre bøger tre stjerner, men som I vil kunne se, er det af forskellige grunde.

Den første anmeldelse er et stykke hårdhændet, men ærligt ment forbrugervejledning. Det er en anmeldelse af den slags, som man ikke skaffer sig venner på i forfatter- og forlæggerkredse:

Ekstra Bladet 5.10.97

ORDBOGSKØBER: SPAR DINE PENGE

Dansk Sprognævn: Retskrivningsordbogen (Aschehoug, 669 sider. 98

$\mathrm{kr}$.)

Jens Axelsen m.fl.: Retskrivnings ordbog (med stavefejl på forsiden)

(Gyldendal, 698 sider. 98 kr.)

Politikens Store nye Nudansk ordbog (1394 sider. 399 kr.)

*** (Tre stjerner)

Når røgen fra den store danske ordbogskrig har lagt sig, vil det vise sig, at der blev skudt med løst krudt.

Den officielle grønne retskrivningsordbog er udkommet i 2. udgave med en del nye opslagsord (som Politiken har trykt). Men retskrivningsændringerne er så få og små, at de kan stå på én side. Og så er der vejledning i noget, som med et reklameudtryk kaldes "det nye komma". Glem det, og sæt kommaer, som du plejer. Altså: Ingen grund til at anskaffe den "nye" grønne, hvis man allerede har den "gamle" stående.

Samtidig udkom - til samme nettopris - et andet forlags afskrift af Retskrivningsordbogen, bare bundet ind i rødt bind. Den røde har nogle flere sammensatte ord og en mere pædagogisk skrevet retskrivningsvejledning - plus en stavefejl på forsiden: "Retskrivnings ordbog". Det skal i ét ord. Altså: Ikke megen grund til at anskaffe den røde kopi, hvis man er ejer af en af de originale grønne.

I morgen affyres så den største fuser af dem alle. Den bærer overbudstitlen Politikens store Nye Nudansk Ordbog. Den udmærker sig rigtignok ved sine ordforklaringer og eksempler, men på grund af en 


\section{4}

idiotisk opblæst layout - lavet af en computer eller et geni med tilsvarende sund sans - er der ikke blevet plads til de navne og ordhistoriske forklaringer, som hidtil har gjort Nudansk Ordbog til noget særligt. Og det på trods af, at formatet er pustet op til det næsten uhåndterlige. For at det ikke skal være løgn, er retskrivningsvejledningen lige så "gammeldansk" som paragrafsproget i den grønne. Altså: Absolut ingen grund til at anskaffe den "nye Nudansk", hvis man er i besiddelse af den gode "gamle" til den halve pris.

Summa summarum: Spar dine penge, til der kommer en ny retskrivning og nogle bedre danske ordbøger.

Den anden anmeldelse har en vinkling, som skulle gøre den interessant for netop avislæsere, og så henleder den opmærksomheden på noget, som kan være en overraskelse for læserne. Her ligger vægten mere på nyheds- og oplysningsværdien end på vurderingen. Meget få læsere kunne formentlig finde på at købe bogen:

Ekstra Bladet 10.2.97

SPROGET I AVISEN

Finn Frandsen (udg.): Medierne og sproget. 181 sider. 175 kr. Aalborg

Universitetsforlag.

*** (Tre stjerner)

Journalister lider under den smukke illusion, at deres sprog skulle være tæt på det almindelige talesprog. I virkeligheden er journalistikken en særlig stil med korte, klare og enkle sætninger, skrevet for travle mennesker i et hurtigt medium.

Det sandsynliggør Finn Frandsen, højaktiv sproglærer på Handelshøjskolen i Århus. Han har stablet en konference om mediesprog på benene og fastholdt otte af indlæggene i en bog med den lige lovlig lovende titel "Medierne og sproget". Bidragyderne taler i øst og vest om engelske avisledere, svenske redaktionsprincipper, politiske plakater, firmabrochurer og tv-tekstning. Det må have været en broget konference. Og den akademiske kongresbog bliver med garanti ingen bestseller.

Men det er vigtigt at få åbnet feltet, for i dag er det sådan, at vi lærer mere sprog af medierne end af hinanden. Den allermest læste teksttype i vore dages Danmark er - tv-tekster!

$\mathrm{Ja}$, slutningen er måske hårtrukken. 
Den tredje og sidste anmeldelse, som altså også bliver mine sidste ord $\mathrm{i}$ denne omgang, er et eksempel på en personorienteret anmeldelse. Nogle vil sige, at jeg går efter manden og ikke bolden. Andre - deriblandt jeg selv - vil mene, at manden her har form som en bold, og at det er fristende at sparke til den. Jeg skal ikke nægte, at det er et skrivestykke, som viser, at anmelderi kan trække på dæmoniske lyster. Se bare hvor mange aggressioner, man kan komme af med på få linjer. Uanset hvad man ellers mener om anmeldelsen, repræsenterer den et stykke sprogligt formningsarbejde.

Ekstra Bladet 8.1.97

STILEN ER MANDEN

Niels Egebak: Prarogativer. Kritiske essays 1966-1996. Redigeret af

Lis Wedell Pape. 198 sider. 198 kr. Aarhus Universitetsforlag *** (Tre stjerner)

Det har ikke altid været let at være Niels Egebak.

Da den unge Egebak vendte hjem fra sine studier i Paris og med store fagter forsøgte at delagtiggøre danskerne i alt det nye i kritikken og litteraturen på venstre Seine-bred, måtte han lide den tort at blive portrætteret som en moderne Jean de France i Rifbjergs satire Marts 1970.

En snes år efter slog alt det, Egebak havde prædiket i tresserne, så igennem i den akademiske lilleverden i en banaliseret amerikansk udgave med det latterlige navn "dekonstruktivisme". Nu omtalte man retningen som "90ernes litteraturteori" og lod nærmest, som om Egebak aldrig havde eksisteret.

Bittert, men også en bitte smule fortjent. For Egebaks stil har altid været en bizar blanding af blær og kævl. Og hans skrivekløe til trods er det aldrig blevet til noget stort banebrydende værk. Læseren må selv gøre arbejdet med at finde guldkornene rundt omkring i de adspredte skrifter.

$\mathrm{Nu}$, hvor den 66-årige Egebak stiger ned fra docentpodiet i Århus, har Lis Wedell Pape gjort ham og hans lille læserskare den tjeneste at samle og ordne en snes centrale filosofiske, æstetiske og politiske Egebak-essays i en bog. Titlen er passende krukket, "Prærogativer". Det smager af præservativer og betyder forrettigheder, fortrin, forhåndsvalg.

Egebak ved, hvad han taler om. Men han tager tonen skingert, når han taler om Roland Barthes og sine andre franske helte. Og lige meget hvilken moderne dansk digter han griber fat i, Inger Christensen, Høj- 


\section{6}

holt eller Søren Ulrik Thomsen, så finder han "materialisme" i deres tekster.

Men det kan man vel ikke bebrejde en mand, der opfatter en litterær tekst som et stykke nodepapir, der skal realiseres af en dirigent.

Uanset hvad Egebak har haft med at gøre, har han altid dirigeret med de samme hoppende armbevægelser.

Stilen er manden.

Der høres spredte klapsalver. 